\title{
生体ゆらぎを模倣したロボット制御
}

中 村 泰*1 松 本 吉 央*2 石 黒 浩*3

\section{A Control Method Imitating a Biological Fluctuation}

\author{
Yutaka Nakamura*1, Yoshio Matsumoto*2 and Hiroshi Ishiguro*3
}

\begin{abstract}
Robots become to be expected to work in our daily lives, but controlling a robot in a real environment by an existing control method would be difficult because it is difficult to model the whole dynamics including the robot and the environment. Since animals can control their body flexibly and robustly in unstructured environments, many robots which reproduce a particular function of an animal have been developed. Despite the progress of these researches, a robot which operates in a real environment has not been developed. In this paper, we focus on the flexibility of biological systems and propose a simple but flexible control method for a robotic system utilizing noise. Experimental results show that our proposed method allows the control of a system without modeling the control target.
\end{abstract}

Key Words: Biological Fluctuation, Attractor Selection Model, Bio-inspired Robotics

\section{1.はじめに}

現在, 実用化されているロボットの多くは工場内など, 構造化 された環境内で活動しているが, 今後は日常生活の場で活動する ロボットが期待されている $[9]$. 杂然とした日常空間など, 構造 化されていない環境で活動するためには, 様々な外乱に対する口 バスト性, 未知の状況にも対応する柔軟性が必要となる。 自律的 に動作するロボットが柔軟性やロバスト性を得るための枠組み として, 強化学習（RL）[20] や遺伝的アルゴリズム（GA）[18] など行動則自体を環境に合わせて学習・変更する手法や, 並列に 動作する単純な行動則モジュールによって複雑な動作を実現す る包摄アーキテクチャ $[1]$ など環境に対して柔軟な行動則を設計 する手法についての研究が行われてきた。しかしながら, 複雑 な構造を持つロボットの制御などモデル化が困難な課題を扱う 場合，モデルを用いた行動則の設計ができないだけでなく，学 習に扔いても多数のパラメー夕を調整するために膨大な試行が 必要となるため, 実環境でも頑健に活動できるロボットシステ ムの開発は困難である.

一方，生物は外乱や環境変動のあるモデル化の困難な自然環

原稿受付 2009 年 10 月 4 日

$* 1$ 大阪大学大学院工学研究科

$* 2$ 産業技術総合研究所

$* 3$ 大阪大学大学院基礎工学研究科

${ }^{* 1}$ Graduate School of Engineering, Osaka University

${ }^{*}$ National Institute of Advanced Industrial Science and Technology

${ }^{* 3}$ Graduate School of Engineering Science, Osaka University

口本論文は提案性で評価されました。
境で自由度の大きい体を利用して柔軟に活動している．生物の 機能に関する研究は盛んに行われてきており [12], 人間と同様 の歩容で歩行する二足歩行ロボット [4] やロバストに歩行する四 足ロボット [6], 周期運動を制御する神経回路を模倣した CPG を用いた二足歩行の研究 [21] やアリの集団行動を模做した最適 化アルゴリズム [5] といった生物の機能を再現する研究が行わ れてきた。 これらの研究では外乱に対してもロバストなシステ ムを実現されているが, 生物の持つ機能を実現するメカニズム を模倣したものであり, 生物が持つ柔軟性を模倣するメカニズ ムではない.

生体は分子レベルから個体, 社会レベルに至る階層を持った 複雑なダイナミクスを持っており, 生体は巧妙にこれらを制御 している. 近年の生物のメカニズムの研究により, 筋肉の運動 や脳内のニューロンの活動等 [25] 生体内の様々な階層の活動に おいてノイズが影響を与えて抢り，バクテリアによる環境への 適応 [11] や確率共鳴による微少な信号の検出 [13] など, 様々 な場面でノイズを有効に利用していることが明らかになってき た，通常の制御などでは，ノイズ等の不確定な要素は避けるべ きものとして扱われているが, 生物はノイズを利用して柔軟で ロバストに活動している．生体がこのようにノイズを有効に利 用する枠組みは, “生体ゆらぎ”と呼ばれ, 盛んに研究されてい る [22] [24] [25].

そこで, 本研究では生体同様に複雑で高次元のダイナミクス を持つ実環境でも活動できるロボットシステムの開発を目標と し, モデル化が困難な対象に対する柔軟な制御する生体ゆらぎ を模倣した，モデル化や学習に基づく従来研究では困難なロボッ トの制御の実現を目指す、本論文では, 生体ゆらぎに基づいた 


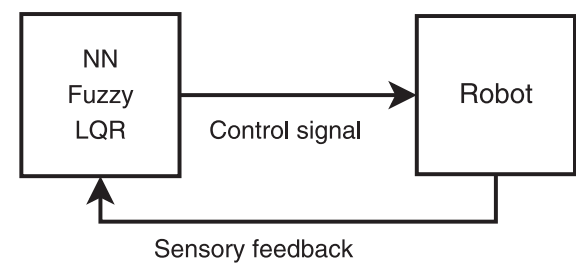

Fig. 1 Block diagram of usual feedback control

ロボットの制御法として, ノイズの存在する環境でノイズを積 極的に利用することで合目的的な振る舞いを生成する単純な移 動ロボット，実環境で柔軟に活動する生体と同様の構造を持つ 生体模做型超複雑なロボットや変動する環境の下で適応的に役 割を選択する複数ロボットシステムの研究を紹介する。

単純な移動ロボット:バクテリアは原始的な生物であり, 単純な 機構であるにもかかわらず環境からの作用を取り込み, 餌 となる化学物質に集まる能力（走化性）を持つ. この走化 性は，本来，前進しかできない 1 自由度の移動機構である にもかかわらず，巧妙に環境内のノイズを利用することに よって実現されている。このメカニズムを模倣することに より，単純であるが機能を持った移動ロボットを開発した

複雑な構造を持つロボット: 脊椎動物などの生物は, 自由度が 高い複雑な体を持って打り，その複雑な体を柔軟に動かす ことにより，様々な動作を行い，外乱に対処することがで きる. しかしながら, その構造の複雑さからモデル化や学 習が困難になるため, 同様の構造を持つロボットを従来の 手法で制御することは困難である. 本研究では人間の上肢 と同様の構造, すなわち 26 種類の人工筋と 7 本のリンク で構成されるロボティックアームを開発し, 生体ゆらぎに 基づく制御法により目的の動作を生成できることを示した。

複数ロボットシステム：複数のロボットを用いてサービスを提 供する場合，ロボットが自律的に自身の役割を決定する枠 組みは重要な基本的機能の一つである。しかしながら，時々 刻々と変化する状況において複数のロボットが自律的に役 割を選択し，適切に協調できるようなルールを前もって与 えることは困難である. 特に, 予測不可能な外乱などの存 在する実環境に扔いては大きな問題となる。そこで，本研 究では生体ゆらぎに基づいた役割の選択法を提案し, 複雑 な環境においても頑健に活動できるシステムを開発した。

通常の制御法では，Fig. 1 に示すように，ニューラルネッ トワーク (NN)，ファジー制御（Fuzzy）や最適レギュレータ （LQR）などの制御器を制御対象のロボットに合わせて設計，学 習することによってロボットの制御を行う，学習を行う場合は GA, Simulated annealing (SA) や RL といった自律的なパ ラメータの学習法が用いられ，Fig. 1 の制御ループにより目的 を達成できるように制御器のパラメータの最適化する，すなわ ち, Fig. 1 の閉ループシステムが適切な振る舞いを実現するよ うにモデル化することによって制御を実現する。

生体ゆらぎに基づく制御法はこれらの既存の手法とは異なり, ダイナミクス自体をノイズにより常にゆらがせ，そのゆらぎの 大きさを制御することにより，妥協可能な振る舞いを生成する 方法である（Fig. 2)。この方法では，システムにノイズを加え

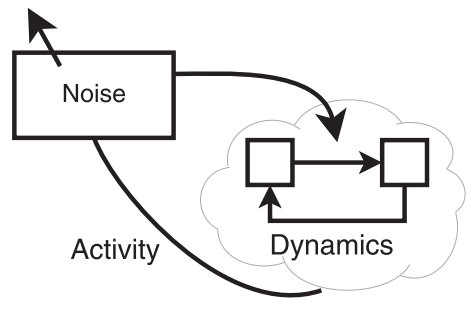

Fig. 2 Control based biological fluctuation

ることで振る舞いを変化させ，その結果得られる振る舞いの変 化のよさを示す指標 “アクティビティ”を利用してノイズの寄 与度を制御する。この相互作用を繰り返すことで “良い振る舞 い”を探索する。

従来の手法と生体ゆらぎに基づく制御法の大きな違いは, 従 来不法がモデル化が正確である，もしくは学習により正確なモ デルが得られることを前提として問題を解いているのに対し, 生 体ゆらぎに基づいた制御法はモデル化が不正確であるという前 提として問題を解決しょうとしていることである. よって, 従 来の方法ではモデル化が不十分であれば，その前提が成り立た ないために解を求めることはできないが，生体ゆらぎに基づく 制御法は，ポテンシャル関数とは独立な観測值であるアクティ ビティを用いてノイズの大きさを制御することで許容可能な準 最適解を探索するものであり，目的や適用範囲は異なる。例え ば，ノイズを利用して探索するという手続きに関しては，熱統 計力学的な解の探索法である $\mathrm{SA}$ と類似した手法である。しか しながら， $\mathrm{SA}$ は温度（ノイズの大きさ）を徐々に小さくしな がら与えられたポテンシャル関数の広域的最小值を探索するこ とを目的としているのに対し，生体ゆらぎに基づく制御法では， ポテンシャル関数を利用しながらアクティビティが十分に大き くなるような振る舞いを探索することを目的としている.

本論文の構成は以下のようになっている，提案手法の基礎と なる生体ゆらぎについて 2 章で説明し， 3 章では生体ゆらぎに 基づくロボット制御の実装と実験について述べる．4 章で制御 法の拡張や今後の課題, 他手法との違いについて議論し 5 章で 結論を述べる。

\section{2. 生体ゆらぎ}

生体ゆらぎは生体内の様々な現象で発見されている。例えば, 筋肉を動かすなどの仕事を行っているミオシン分子モー夕の運 動は熱ゆらぎ，すなわちノイズで駆動される。また，Kashiwagi らは, 大腸菌が遺伝子の発現量を変化させることによって行う環 境適応の振る舞いをアトラク夕選択モデルと呼ばれる数理モデ ルで説明した [11].この生体ゆらぎのモデルのダイナミクスはラ ンジュバン方程式で表され，ノイズの効果を制御することによっ てシステムの振る舞いを制御している，本章では，生体ゆらぎを シンプルに説明するアトラクタ選択モデルについての説明を行う.

\section{1 アトラクタ選択モデル}

アトラクタ選択モデルの概念はランジュバン方程式：

$$
\tau_{x} \dot{x}=-\nabla U(x) A+\epsilon,
$$

によって説明できる。 ここで, $x$ と $U(x)$ はそれぞれアトラク 夕選択モデルの状態とポテンシャル関数で, $\tau_{x}$ と $\epsilon$ は時定数と 


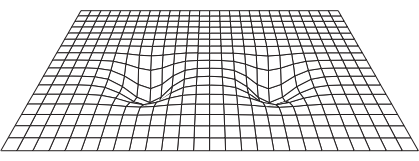

(a) Potential function

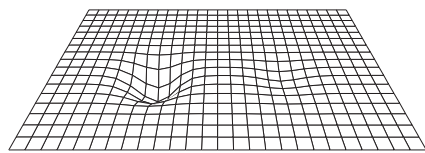

(b) Effective landscape

Fig. 3 Attractor selection model

ノイズである。ポテンシャル関数 $U(x)$ は, Fig. $3(\mathrm{a})$ に示す ように前もって埋め込まれた解候補の状態を極小值（アトラク 夕）として持つ関数で, アトラク夕選択モデルでは, ノイズを 利用して環境に適したアトラクタを探索する.

$A$ は “アクティビティ”と呼ばれる変数で, 状態 $x$ の環境へ の適合度を示し, この変数によってアトラク夕選択モデルの挙 動が変わる，すなわち，アクテイビテイが大きくなると式 (1) の $\nabla U(x) A$ が支配的になり, 状態遷移は決定論的なものへと 近づく，一方，アクティビティが小さくなるとノイズ $\epsilon$ の効果 が支配的になり，状態遷移はよりランダムウォークに近づく．

アクティビティは大腸菌の例では栄養素の充足度といった現 在のよさを表すもので, 現在の状態が環境に適合しているとき に大きく，適合していないときに小さくなるような指標である. よって, Fig. 3 (a) の右側半分に执いてアクティビティが小さく, 左側半分において大きくなるような環境では, 元々のポテンシャ ル関数 $U(x)$ の持つ極小值（アトラク夕）のうち, 右側のアト ラクタは実効的には効果をなくし，ランダムウォークによって 適切な（アクティビティの大きくなる）アトラクタの探索を行 う. すなわち, 実効的なポテンシャル場は Fig. 3(b)のように なり, 最終的にはアトラク夕選択モデルの状態は環境に適合し たアトラクタへと引き込まれる。

ポテンシャル関数とアクティビティ

モデル化が困難な問題では, 問題を解決するためのポテンシャ ル関数を構築することは困難である. 一方, 問題がどの程度, 解 決できているかを示す指標は例えば，大腸菌に扔ける栄養素の 充足度やロボットによるリーチングタスクに扔ける手先とター ゲットの距離など，比較的簡単な方法で得られる場合がある。す なわち, 遺伝子の発現パターンや筋肉の活性度といった状態に 対して, どのような状態がどの程度よいかを示すポテンシャル 関数を構築することは困難であるが, 現在どの程度の目的が達 成できているかを直接計測できる場合には，この指標を利用し てアクティビティとすることができる.

モデル化が困難な問題では真のポテンシャル関数を得ること は困難なため, 任意の関数 $u(x)$ （近似ポテンシャル関数と呼 ぶ）で真のポテンシャル関数を置き換えると, ランジュバン方 程式は,

$$
\tau_{x} \dot{x}=-\nabla u(x) A+\epsilon,
$$

のように書き換えられる。ここで, 真のポテンシャル関数 (Fig. 4) は得られていないが, 真のポテンシャル関数のポテ ンシャルが小さくなる状態では, アクティビティが大きな值と

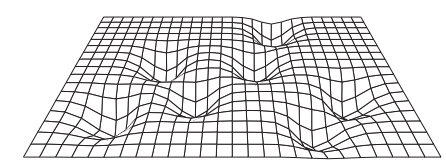

Fig. 4 True potential field

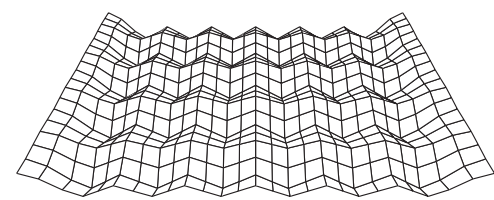

(a) Approximate potential function

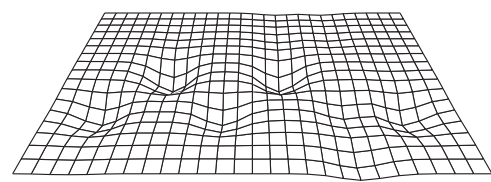

(b) Effective landscape

Fig. 5 Change of the effective landscape by modulation of the activity

なると仮定する．また，Fig. 5 (a) に示すような多数のアトラク 夕を持つ近似ポテンシャル関数を用いると, アクティビティが 小さくなるようなアトラク夕は実効的には無視されるため, ポ テンシャル関数の実効的なランドスケープはアクティビティに 修飾され Fig. 5 (b) のように真のポテンシャル関数と類似したも のとなることが期待できる。すなわち, 適当なポテンシャル関 数を用いても, このメカニズムはロバストに働く可能性を持つ.

アトラクタ選択モデルではランジュバン方程式を明に解くの ではなく、ランダムさをアクテイビティにより制御することに より，不正確なポテンシャル関数を持つ場合にも適切なアトラ ク夕を選択することができる枠組みである。すなわち，制御対 象の正確なモデルを前提とする通常の制御法とは異なり，モデ ルが不正確であることを前提として抢り, 従来の方法がモデル 化されたパラメー夕空間内で最適值（最適解）を探索・計算し ているのに対して，生体ゆらぎに打いてはパラメータ空間とは 独立の観測值であるアクティビティを利用して振る舞いを変え, 準最適解を探索する。このような性質から，モデル化が困難な 対象を制御する場合にであっても，“生体ゆらぎ”の性質を利用 することで適切な振る舞いを生成できると期待できる。

\section{3. ロボット制御への応用}

最適制御などの従来の制御手法は正確なモデルを前提として 問題を解決しようとするために，モデルが正確であればそのモ デルに基づき制御を行う（モデルを利用して解を求める）こと で高速な応答や正確な動作が可能である。しかし，モデル化が 不十分であればその解は正しいものとはならないために, 適切 に制御することはできない，また，学習手法などの様々なシス テム同定の手法により，正確なモデル化を目指した研究も行わ れているが，実環境で動くロボットや複雑な構造を持ったロボッ 卜は多くの自由度を持っていたり, 環境の変動や外乱の存在に より正確なモデル化は困難となる。一方，アトラク夕選択モデ ルはアクティビティによりノイズの大きさ，すなわちランダム 性の強さを制御することにより，アクティビティの大きくなる 
アトラクタに引き达まれる現象を利用して目的に合致した（ア クティビティの大きくなる）振る舞いを生成するメカニズムで ある。そのため, アトラク夕選択モデルは正確なモデル化を前 提とせずに適切な振る舞いを生成することができる，本研究で は，この振る舞いのランダムさを能動的に制御することにより, 制御対象のロボットや環境のモデル化を行うことなく，ロボッ トを制御する枠組みを提案する。

生体ゆらぎに基づき設計したロボットシステムについて三つ の例を示す。はじめに, 物理的なノイズを利用した単純な移動口 ボットについて説明する。このロボットの制御法は明に式（1） を利用した方法ではないが，ノイズを受けやすい動作と受けに くい動作の比率をアクティビティによって制御することにより, アトラクタ選択モデルと同様にランダム性の強さを変化させる ことで合目的的に振る舞う。また, 多様なノイズを持つ環境に おいて環境のモデル化を行わない単純な制御法であり, 単純な 構造を持つロボットが積極的に環境のノイズを利用することで ロボット自体の持つ自由度よりも大きな空間での移動を実現し ている. 次に, 自由度の大きい複雑な構造を持つロボットであ る人間型ロボティックアームの制御にアトラクタ選択モデルに 基づく制御法を適用した結果について紹介する。このロボット は人間の上肢と同様の骨格を持ち, 人間の筋肉と同様に配置さ れた人工筋により駆動される。自由度が大きくモデル化が困難 な対象であるが, 振る舞いのランダムさを能動的に制御するこ とにより，モデル化を行わずに適切な動作を実現することがで きた. 最後に, 提案手法を動的に変化する環境で働く複数の口 ボットによる動的なタスク割り当て課題へ適用した場合につい て説明する。

\section{1 バクテリアを規範とした移動ロボット}

バクテリアは生存に必要な化学物質（誘引物質）濃度が高いほ うへ移動する能力 (走化性) を持つ [14]. この走化性は体前方の 化学物質濃度を感知する一つのセンサを用い, センサで検出し た化学物質濃度が増減によりべん毛の回転方向を変化させるこ とで実現される，すべてのべん毛が反時計回りに回転すると，ベ ん毛はまとまってスクリューのように働き前進する（Fig. 6 (a) A). それ以外の場合には, 多数のべん毛が拡がることにより周 囲のノイズを受け, 方向転換を行う（Fig.6(a) B). 化学物質 濃度の増加を検出したときに前者の頻度が増加し, 逆に減少し たときに後者の頻度が増加することが明らかになっており [14], これは環境から与えられるノイズが運動に与える影響の大きさ を化学物質濃度の変化で制御していると捉えることができる。

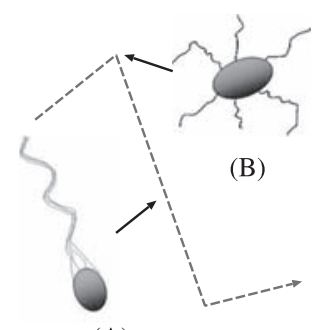

(A)

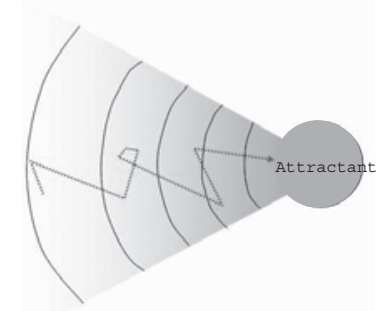

(b) Chemotaxis (a) Swimming and tumbling modes

Fig. 6 Motion of a bacterium
環境への適合度, すなわちアクティビティ, を示す生存に必要 な化学物質の量によりノイズを制御する “生体ゆらぎ”のメカ ニズムに基づいた制御法となっている。

Fig. 7 (a) は本研究で開発した液中で動作する 1 センサ 1 自 由度ロボットである [19].このロボットは前方に搭載したフォ トダイオードにより光の強さを計測し, 後方のスクリューで移 動する、また，構造上，スクリューを正回転させた場合には前 進するが, 逆回転させた場合には波や構造の非対称性, モー夕 の振動などの環境の影響から方向をランダムに変化させるもの となっており, バクテリアと同様の振る舞いが期待できる。 ま た, アクティビティとしてフォトダイオードの受光量の増減を 用い, 受光量が増加した場合には正回転する, 減少した場合に は逆回転する確率を増加させるものとした.

光源となる蛍光灯を円周上の一点に接地し, フッ素不活性液 を満たした直径 $35[\mathrm{~cm}]$ の水槽内で, このロボットを動作させ た場合の移動軌跡を Fig. 7 (b) に示す. 各マークは受光量の変 化を示しており, 四角 $(\square)$, 菱形 $(\diamond),+$ マーク, ×マーク の順番で増加分が大きいことを示しており, ロボットが光源に 近づく場合に大きくなる傾向がある. Fig. 7 (b) の左下の棒グラ フはロボットが光源に近い領域（A）と遠い領域（B）に滞在し た時間の割合を求めたものである. 3 分間の試行を 10 回行い, 滞在時間の平均と標準偏差を図示している. すなわち, 光源に 近い領域に滞在する時間は光源から遠い領域に滞在する時間よ りも有意に長くなっており，走光性を持つことが示された.

このロボットは, 制御信号としてはスクリューを回転させる モータを回転させるだけで動作する 1 自由度のロボットである が，ノイズの効果を制御するだけで二次元空間を移動できるも のとなっている。すなわち，このロボットは環境からの“ゆら

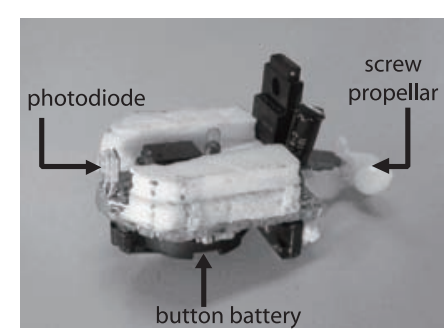

(a) 1-DOF robot

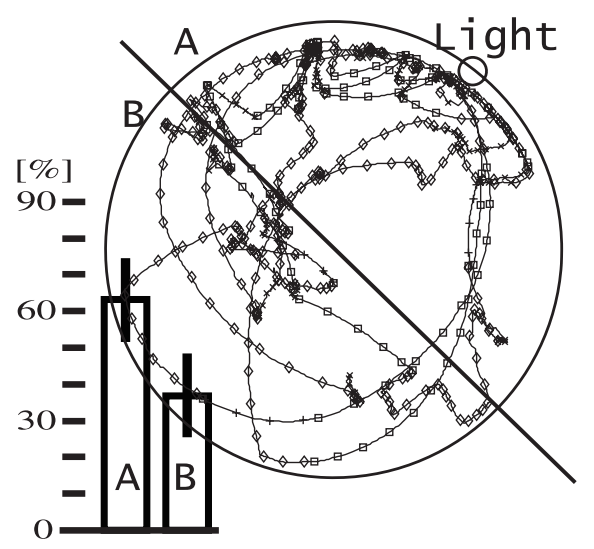

(b) Trajectory

Fig. 7 1-DOF robot and its behavior 


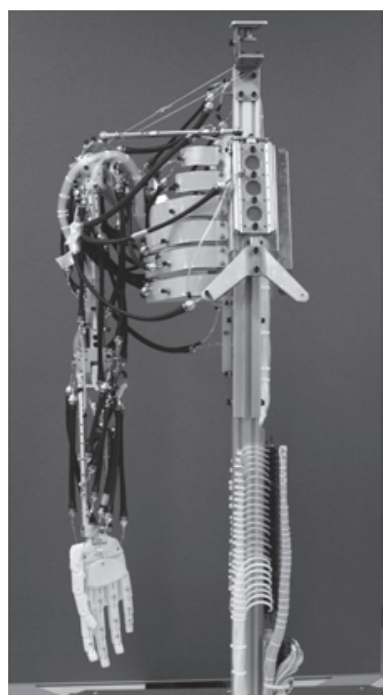

(a) Frontal view

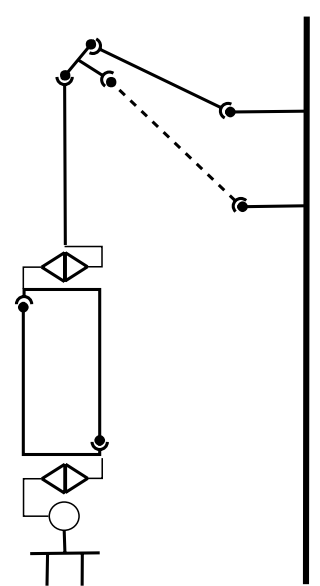

(b) Joints and links
Fig. 8 Human-like robotic arm

ぎ”を利用することにより，自身の持つ自由度より大きな空間 で走性を実現するロボットとなっている.

\section{2 人間型ロボティックアーム}

Fig. 8 に示す人間の上肢をモデル化した人間型ロボティック アームの制御実験を行った。 このロボットは, 人間と同様に 7 本のリンクからなる骨格に, 26 種類の人工筋を人間と同様に配 置したものとなっており, その構造から人間の上肢と同様に柔 軟でロバストな動作が行えると期待できる. 人工筋としては, 空 気圧型人工筋であるマッキベン型アクチュエータを用い, それ ぞれ筋の空気圧を流量制御弁を用いて制御することにより駆動 される。このロボットは, 目的の動作を実現するための自由度 を組み合わせることにより製作される通常のロボット $[8]$ とは 異なり，どのアクチュエータがどのような動作に影響を与える かが不明であるなど，モデル化が困難なものとなっている，そ のため, 通常の制御理論などを用いることは困難であり, 自由 度が大きいことから強化学習のような学習理論に基づく最適化 手法を用いても膨大な試行錯誤が必要になるなどの問題が起こ る [15] [20].

Fig. 9 にアトラクタ選択モデルに基づくロボティックアーム 制御のブロックダイアグラムを示す。時刻 $t$ において，ロボッ トの状態に基づきアクティビティ $A(t)$ が計測され，アトラク 夕選択モデルに入力される。アトラクタ選択モデルは近似ポテ ンシャル関数 $u(x)$ を用い状態を $x(t-1)$ から $x(t)$ に変化さ せ, アトラク夕選択モデルはその状態に基づき, ロボットに対 する制御信号 $a(t)=\Omega(x(t))$ を出力する。ここで, $\Omega(\cdot)$ は適 当な関数である。ロボットは制御信号 $a(t)$ を受け取り, その状 態 $s$ を

$$
\dot{s}=\mathcal{D}(s, a),
$$

のように変化させる.ここで, $\mathcal{D}(s, a)$ はロボットのダイナミク スである。

このとき, ロボットの状態とアトラクタ選択モデルの状態を 合わせた状態 $z=\left[x^{\top}, s^{\top}\right]^{\top}$ は全体として高次元のダイナミク

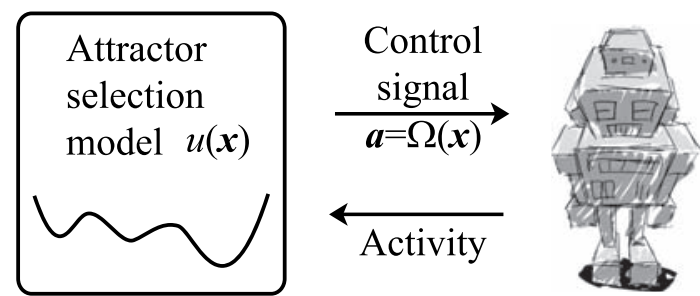

Fig. 9 Block diagram

スとなっており, アクティビティ $A$ が大きい場合には $x$ が決 定論的になるために全体としても決定論的に振る舞い, 小さい 場合には $x$ の振る舞いは確率的になっており, 全体としても確 率的な振る舞いを行う。すなわち, ロボットとアトラク夕選択 モデルを合わせた一つのシステムとして，アトラク夕選択モデ ルによって制御されることになる.

\section{2 .1 アトラクタの設計}

本研究では, 近似ポテンシャル関数 $u(x)$ として混合ガウス 関数:

$$
u(x)=-\frac{1}{N} \sum_{i=1}^{N} G_{i}(x),
$$

を用いた。 ここで, $G_{i}(x)$ は中心 $\bar{x}_{i}$ と幅 $\sigma$ を持つガウス関数 で, $G_{i}(x)=\left(2 \pi \sigma^{2}\right)^{-D / 2} \exp \left\{\left(-1 / 2 \sigma^{2}\right)\left|x-\bar{x}_{i}\right|^{2}\right\}$, で定義 される。 また, $N$ はガウス関数の数である。 この式を用いた場 合, それぞれのガウス関数がアトラクタとなるため, ガウス関 数を適当に配置することでアトラク夕を生成することができる. ノイズの影響を受けない場合のこのシステムの振る舞いは, 多 数の物体（アトラクタ）に生成される重力場を動き回る質点と 同様のものとなる.

ロボテイックアームに対する制御信号は各流量制御弁に対す る制御信号の 26 次元である. 今回は, 20 個のアトラクタ,す なわち, 各ガウス関数の中心 $\bar{x}_{i}$ を乱数により生成した近似ポ テンシャル関数を用いた。 また, 本実験では, ランジュバン方 程式（2）の代わりに，ランダムサンプリング法の一種である リジェクションサンプリング法を用いてアトラクタ選択モデル の状態を変化させた。この方法は, ポテンシャル関数の勾配で はなく，值を直接用いて状態を更新する方法であり，一度の状 態遷移の大きさがポテンシャル関数の勾配の大きさに依存しな いという特徴を持つ。一方, アクティビティが大きいときには アトラクタに引き込まれ，小さいときにはランダムに移動する という性質に関しては，ランジュバン方程式を用いた場合と同 様であるため, アクティビティによりシステムの振る舞いのラ ンダムさを制御することができる。また，ランジュバン方程式 （2）では，アクティビティ $A$ は $\nabla U(\cdot)$ との積となっていたが, 今回は, アクティビティによりガウス関数の幅 $\sigma$ を制御するも のとし， $\sigma=1 / A$ とした. この方法では, アクティビティが大 きい場合, 細く尖ったポテンシャル場が, 小さい場合には広く なめらかなポテンシャル場となる.

\section{2 .2 リーチングタスク}

簡単のため制御の目的はロボットの手首の位置を一定の高さ $(220[\mathrm{~mm}])$ に静止させることとした実験を行った。手首の高 


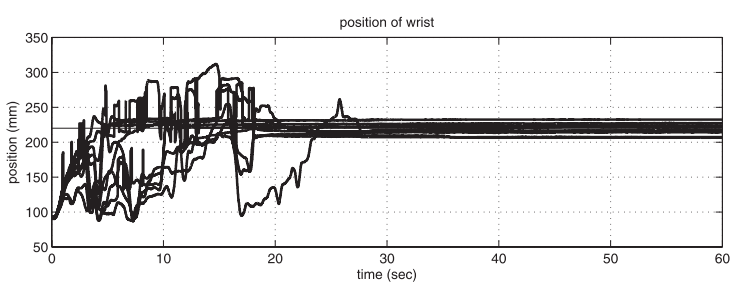

Fig. 10 Movements of the wrist (Target height $=220[\mathrm{~mm}]$ )

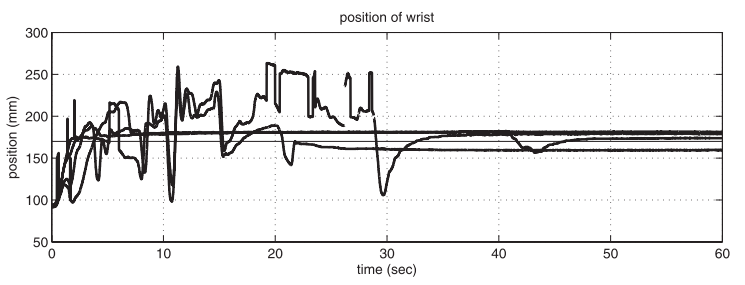

(a) Successful trials

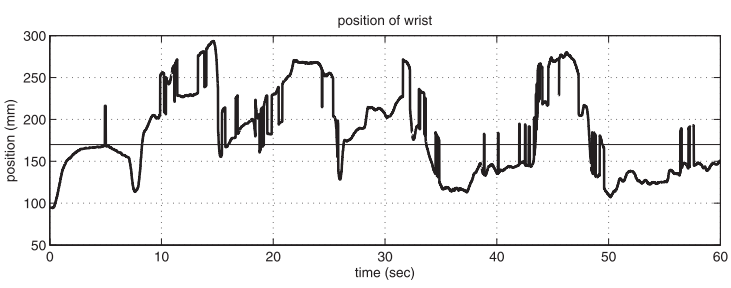

(b) A failure trial

Fig. 11 Movements of the wrist (Target height $=170[\mathrm{~mm}]$ )

さをモーションキャプチャシステムで計測し，アクティビティ

$$
A(t)=\mathcal{A}_{p}(\alpha(t))+\mathcal{A}_{d}(\alpha(t)-\bar{\alpha}(t))
$$

と定義した。ここで， $\alpha$ は目標点とロボットの手首位置との距 離の逆数であり, $\bar{\alpha}$ は忘却係数 $\gamma$ で重みづけられた $\alpha$ の平均 である. $\alpha(t)-\bar{\alpha}(t)$ は瞬間的な夕スク達成度の改善量を示して いる. また, $\mathcal{A}_{p}$ と $\mathcal{A}_{d}$ は単調増加の関数である。 よって, ア クティビティはゴールに近づくか, ゴールに近いときに大きな 值となる。また， ロボットに対する制御信号は最小值と最大值 を制限するために $\Omega(x) \equiv 4+1.5 \tanh (10 x)$ を用いて出力す るものとした。この最大值と最小值の場合には人工筋は瞬時に 収縮または伸長する。

Fig. 10 に制御の結果を示す。近似ポテンシャル関数のアトラ クタの位置をランダムに変えて 10 回の実験を行った場合の手首 の高さを変化を重ねて示しており, 縦軸が高さ, 横軸は時刻を 時間を示している.すべての実験で目標に近い高さを保持して いることが分かる.アトラク夕選択モデルによる制御法は非常 にシンプルな方法であるにもかかわらず, 手首の高さを目標の 高さに維持できた，目標高さを $170[\mathrm{~mm}]$ に変えて同様に 10 回 の試行を行ったところ, 成功が 4 例 (Fig. 11 (a)), 一時的に成 功したものが 2 例, と Fig. 11 (b) に示すような失敗が 4 例あっ た，高さを変えた場合に失敗例が起こった理由としては，手首 が目標の高さとなる姿勢によっては, 探索に時間を要する場合 があることが考えられる。この場合, Fig. 11 (b) に示すような 失敗例では探索を続けていることから，より長時間の制御によ り目的の姿勢の探索し, 手首の高さを維持できる可能性がある.

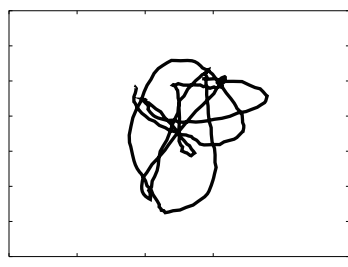

(a) $0 \sim 5[\mathrm{~s}]$

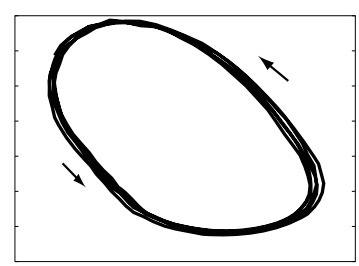

(b) $15 \sim 20[\mathrm{~s}]$
Fig. 12 Trajectories of the wrist

\section{2 .3 円軌道タスク}

次に, 水平面に写像した手首の運動軌跡が円軌道を描くよ うに腕を動かすことを目的とした実験を行った。ロボットへの 制御信号を周期信号に制限するものとし, 制御信号は三角関 数で定義し, アトラクタ選択モデルの出力により, 各アクチュ エータへの制御信号の位相を決定するものとした。すなわち, $\Omega(x ; \tau) \equiv 4+2 \sin 2 \pi(\tau / T+x)$ で定義した. ここで, $\tau$ と $T$ はそれぞれ時刻と運動の周期である.アトラク夕選択モデルの 状態 $x$ の変化により位相が変化するが, 円軌道を生成するため には適切な順序で筋を活性化する必要がある。また，アクティ ビティは手首の位置の移動平均を中心と仮定した場合の現在の 手先の位置における接線と手首の速度の内積を用いて定義した。

Fig. 12 に生成された手首の運動軌跡の一例を示す. Fig. 12 (a) は運動開始直後の軌跡を示しており, アクティビティが低く, ランダムに運動を変化させている状態の軌跡である. Fig. 12 (b) はある程度の時間が経過したあと, アクティビティが上昇し, 安 定した円軌道を描く運動に収束したあとの軌跡である。5 分間 の制御を 10 回行ったうち, 4 回の試行で同様の円軌道運動を生 成することができた。

\section{3 複数ロボットへのタスク割り当て}

複数ロボットシステムにとってタスク割り当ては基本的な機 能である。しかし，実世界でタスク割り当てを行おうとすると， 人間の出入りやドアの開閉, 様々な障害物など割り当てを行う ためには多数の要因が存在し, その状況も時間とともに変化す る. また, その環境の変化もモデル化が困難なことから非常に 複雑で困難な課題であり, 様々な研究が行われてきた. 一方, 群 れで行動する生物は複雑な状況でも, 各個体が整然と群の一部 として行動することができる. 本研究では, 各個体が自身の近 辺の情報だけを利用したタスクの選択課題にアトラクタ選択モ デルに基づく制御法を適用した $[2]$.

シミュレーション実験の目的は Fig. 13 に示すような環境に おいて, 6 台のロボットで環境中に散乱しているゴミを除去す るものである. Fig. 13 (a) と 13 (b) は, それぞれ 2 部屋と 4 部屋に区切られており, ドアが閉った状態では他の部屋に移動 できないものとする，また，ドアの開け閉めの頻度を変えて実 験を行い，常にドアが開放された場合， 1,000 ステップにそれ ぞれ $2,5,10$ と 15 回のドアの開閉が起こる場合について実験 を行った。

Fig. 13 内の右上隅の四角と中央の円はそれぞれゴミ捨て場所 (Dump area) とゴミ箱（Dust box）である.ロボットは“ゴ ミを一カ所に集める（G：gather dusts）”, “ゴミをゴミ箱へ運 ぶ (C : carry dusts)”, “ゴミ箱のゴミをダストシュートに捨て 


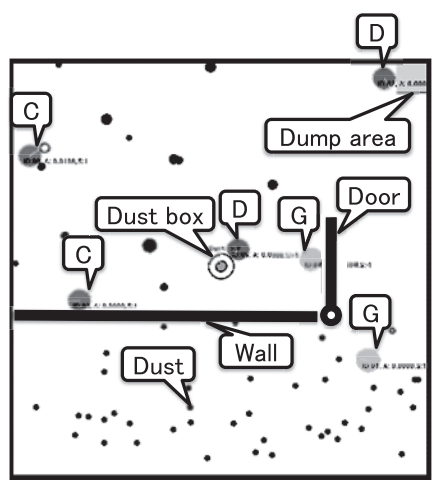

(a) Environment 1 (2 rooms)

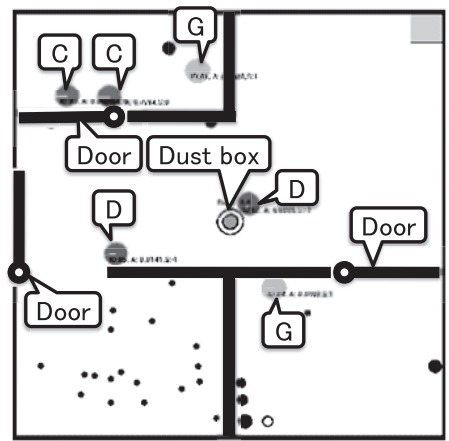

(b) Environment 2 (4 rooms)

Fig. 13 Dynamic task assignment for a multi robot system

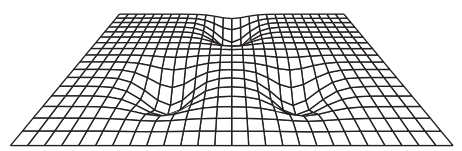

Fig. 14 Potential function for task selection

る (D : take the dust box to the dump area)"の 3 種類の夕 スクの中からタスクを選択し作業を行うものとし， G, C と D の吹き出しの付いた円はそれぞれのタスクを選択したロボット を示している。ロボットはタスクを選択すると適切なアルゴリ ズムにより，タスクの目的を満たす行動を実行できるものとす る。また，ロボットに取りつけられたセンサはロボットの近傍 のゴミや障害物を認識できるものとし，また，ロボットは環境 のマップ（壁やダストシュートの位置）などはあらかじめ記憶 しているものとした

この課題では，それぞれのロボットがどの夕スクを選択する かが問題となる，そこで，アトラク夕選択モデルに基づきタスク を選択する手法を提案する，提案手法では，ロボットが Fig. 14 に示すポテンシャル関数が与えられた内部状態（二次元ベクト ル）を持ち，現在の内部状態にもっとも近いアトラクタに割り 当てられたタスクを選択する。この内部状態の状態遷移はアト ラクタ選択モデルに従うものとする。このとき，ポテンシャル 関数の対称性から，アクティビティが常に一定であれば $1 / 3$ の 確率でそれぞれのタスクが選択されることとなる。

ロボット $i$ のアクティビティ $A_{i}(t)$ は，ロボット $i$ が観測し たゴミの数の変化によって計算される. 時刻 $t$ に扔いてロボッ ト $i$ が $g_{i}(t)$ 個のゴミを認識したとすると, ロボット $i$ のアク ティビティを

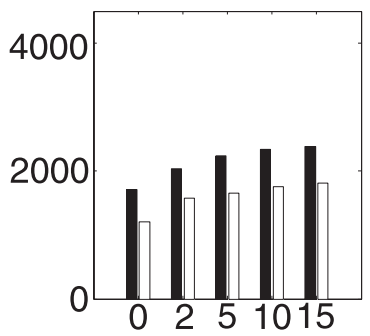

(a) Environment 1 (2 rooms)

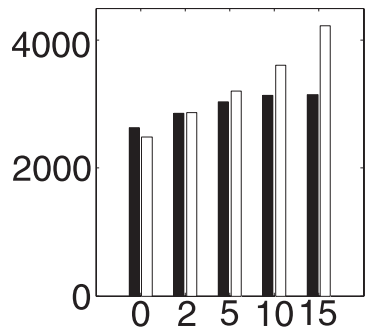

Fig. 15 Elapsed time

$$
A_{i}(t)=-(g(t)-\bar{g}(t))
$$

と定義した．ただし， $\bar{g}(t)=0.1 g(t)+0.9 \bar{g}(t-1)$ で計算され る観測したゴミの量のオンライン平均で, アクティビティはゴ ミの増分に相当する。

Fig. 15 にゴミ処理に要した時間を示す. Fig. 15 (a) と 15 (b) はそれぞれ環境 1 と 2 で要した時間であり, 各図, 黒と灰色の 棒グラフの值はそれぞれ提案手法を用いてロボットがタスクを 選択した場合と，それぞれのロボットに前もって決まったタスク を与えた場合（各タスクに 2 台ずつ割り当て）に要した時間を 示している. 比較的環境が単純な環境 1 においては役割を固定 した場合のほうが早くゴミを除去できているが，環境が複雑に なるに従い, 必要とする時間が増加している. 一方, 提案手法 は，単純な環境に扔いては効率が悪いが, 環境が複雑になった場 合に必要とする時間の増加が少ない. すなわち, 様々な外乱の 存在する実環境において有利な特性を持っていると期待できる。

\section{4. “生体ゆらぎ”の展開と課題}

前章では，生体ゆらぎに基づくロボット制御の例を示した。 これらの制御はノイズの寄与分を制御することを基本とした制 御法となっており, 制御対象に対するモデル化は行っていない にもかかわらず，適切な振る舞いを生成することができた。す なわち, Fig. 1 の閉ループシステムの設計や学習を行うことな く, Fig. 2 に示すように，ダイナミクス全体にゆらぎを加える ことでシステムの制御を実現できることを示した，効率に関し ては閉ループシステムの持つダイナミクス自体を最適化，すな わちモデル化することは有効であるが，学習の初期段階や，予 測不可能な外乱が発生するなどのモデル化が困難な環境におい て、モデル化を必要としない提案手法は有効であると考えられ る。従来の方法だけではなく, 生体ゆらぎに基づくモデルを必 要としない制御手法は今後, モデル化の困難な実環境で活動す るロボットにとって重要であると考えられる.

生体ゆらぎは, 筋肉を駆動する熱ノイズ [25], 多義図形の認識 における自発的なゆらぎや環境に応じた遺伝子の発現パターン の変化 [11] だけでなく, 細胞が自発的な運動にも見られ, 自発 的なランダムウォークはブラウン運動ではなく、べき法則に則っ た振る舞いであることが調べられた[22]，また，Lèvy walk [23] はべき法則に従うランダムウォークであり，動物が餌を探索す る場合などの振る舞いによく見られ，探索の対象がスパースで あるときなどにはブラウン運動よりも効率よく探索できること が知られている。ささらに，生体内でのゆらぎの大きさと応答性 
が正の相関を持つことも明らかになってきており [17], 今回の 研究では一般的な正規乱数を利用していたが, ノイズを有効に 利用する工夫が必要であると考えられる.

生物は階層的な多数の要素が一貫性を持って活動することで, 全体として適切に動作しており [10] [25], 既存の人工システムと の主な違いとして並列性と階層性が挙げられる. 多数の要素か らなるシステムは, 圥長であるため要素の故障などについてロ バストであり，実環境において有効であると考えられる，近年， 多数のアクチュエータを適切なグループに割り当て, グループご とに駆動することによって制御するロボットハンドが開発され た [3]. このような多数の要素で構成されるシステムに対する制御 へ生体ゆらぎに基づく制御法を適用することは今後の課題である.

以下に，生体ゆらぎに基づく制御法に対する現在の取り組み を説明する。

\section{1 適応的アトラクタ選択モデル}

2.1 節において, 近似ポテンシャル関数を用いた場合でもア クティビティによる修飾の効果から実効的な探索が真のポテン シャル関数を用いた場合に近いものになることが期待できると 述べた。また, 人間型ロボティックアームの制御において, ア トラクタをランダムに配置したにもかかわらず, 目的にあった 振る舞いを生成できたことから，アトラク夕選択モデルに基づ く方法ではモデル化を行わずにロボットの制御ができることを 示した。 しかしながら, 効率の面では近似ポテンシャル関数が 真のポテンシャル関数に近いほうがよりよく, 制御対象のモデ ルが利用可能であれば, モデルを利用してポテンシャル関数を 設計・学習を行うことで制御の効率が向上すると考えられる.

そこで我々はクラスタリング手法に基づきアトラクタの再配 置を行う適応的アトラクタ選択モデルを提案した [7]. アトラク 夕選択モデルにおいては，アクティビティが大きくなる頻度が 高い状態は良い状態である可能性が高いと考えられる。よって, そのような状態にアトラクタを配置し, その状態に引き込まれ ることで性能が向上すると考えられる。 そこで, 経験によって 得た状態の履歴に対してアクティビティで重みをつけたクラス タリングを行うことで，近似ポテンシャル関数を更新する.

この提案手法を, ポールを一定角速度 $\hat{\theta}$ で回転させる夕スク に適用した. 制御信号は, ポールに加える力で, アトラク夕選 択モデルが出力する仮想的な目標角速度 $x$ と現在の角速度 $\dot{\theta} の$ 差を用いて $u \equiv-k(x-\dot{\theta})$ で与えられるものとした。このと き, ポールには重力が加わっているため, ポールを一定速度で回 転させるためには，振り上げるときには真の目標角速度 $\hat{\theta} よ り$ も大きく, 振り下ろすときには小さい值をアトラク夕選択モデ ルが出力する必要がある. 適応的アトラク夕選択モデルでアト ラクタの再配置を行った結果, 振り上げと振り下ろしのための 適切なアトラクタが生成された。 それらのアトラクタを適切に 選択することで, 角速度に関する自乗誤差はアトラク夕選択モ デルの出力の代わりに真の目標角速度 $\hat{\theta}$ を用いた場合 (0.022) よりも小さい值 $(0.0056)$ となり, 適切なアトラク夕の配置に より効率が向上することが分かった.

\section{2 Lèvy walk}

生体ゆらぎのロボット制御への応用において, 本論文で提案 した手法では, 環境のゆらぎを利用する単純な移動ロボットを
除くとガウス分布に従うノイズを利用している。生体ゆらぎに おいてノイズの性質は, 探索の効率を変化させる重要な役割を になっており，有効に利用できるノイズの性質を探ることは今 後の課題である.

近年, ガウス分布等に比べて裾の重い分布であるべき乗則に 従うランダムウォークである Lèvy walk が注目されている.こ のランダムウォークは, いわゆるブラウン運動とは異なり, 近 傍の探索と広域的な探索を行うランダムウォークになっており, 探索対象がスパースである場合に通常のブラウン運動よりも効 率的であることが知られている. 現在, 我々は Lèvy walkに基 づく適応的な探索メカニズムについての研究に取り組んでおり, 局所的な探索を行うブラウン運動と組み合わせることでより効 率的な探索を行えるモデルの構築を目指している [16].

\section{3 階層化}

生体は分子レベルから細胞レベルといった様々なスケールの ダイナミクスが相互に作用し合う複雑なシステムである [25]. 例 えば, 筋肉は多数の筋繊維で構成されており, その筋肉が多数 集まって手や脚などを動かしている。ロボットの制御において も，“取る”，“置く”，“投げる”といったタスクレベルの制御, そのタスクを実現する“曲げる”, “伸ばす”, “握る”といった 基本動作レベルの制御や，その動作を実現する筋肉の活性度の 制御といった階層に分割することができる。このような階層的 を持った複雑なシステムを制御するための仕組みとして, アク ティビティを伝搬することにより階層的な制御を行う枠組みが 必要になると考えられる。

\section{5. 結論}

本論文では，複雑でモデル化が困難で従来手法が適用できな い課題を解決する方法として, 複雑で高次元のシステムである 生体を巧妙に制御する仕組みである “生体ゆらぎ”を利用した制 御法を提案した。この制御法では複雑なロボットのモデル化を 行わず，現在の状態の良さを示すアクティビティに基づき，ノ イズの寄与の大きさを制御することによって目標のタスクを達 成する新しい枠組みである。この枠組みに基づいた 1 自由度 1 センサの単純な移動ロボット, 人間の上肢と同様の構造を超複 雑ロボティックアーム制御と複数ロボットに対する動的なタス ク割り当て課題において，ノイズを利用することにより制御が 可能であることを示した．

生体ゆらぎに基づくロボット制御において課題となっている, 適応的メカニズムと探索に適したノイズに関する研究について 紹介し，より複雑なシステムを制御する場合に必要となると考 えられる階層化制御について述べた。これらの課題に取り組む とともに，モデル化を用いる従来手法との組み合わせにより，効 率と柔軟性を兼ね備えた手法の研究を行うことも今後の課題で ある。

謝 辞 本研究は, 文部科学省科学技術振興調整費「先端融 合領域イノベーション創出拠点の形成：ゆらぎプロジェクト」の 研究助成によるものである。ここに記して謝意を表す.

\section{参 考 文 献}

[1] R.A. Brooks: "Intelligence without representation," Artificial 
Intelligence, vol.47, pp.138-159, 1991.

[2] E. Castello, S. Koizumi, Y. Nakamura, Y. Matsumoto and H. Ishiguro: "Dynamic task assignment for a multi-robot system based on the attractor selection model," 情報処理学会関西 支部 支部大会, 2009 .

[3] K. Cho and H.H. Asada: "Architecture design of a multiaxis cellular actuator array using segmented binary control of shape memory alloy," IEEE transactions on robotics, vol.22, no.4, pp.831-843, 2006.

[4] S. Collins, A. Ruina, R. Tedrake and M. Wisse: "Efficient bipedal robots based on passive-dynamics walkers," Science, vol.307, pp.1082-1085, 2005.

[ 5 ] M. Dorigo, G. Di Caro and L.M. Gambardella: "Ant algorithms for discrete optimization," Artificial Life, vol.5, pp.137-172, 1999.

[6] Y. Fukuoka and H. Kimura: "Biologically inspired adaptive dynamic walking of a quadruped on irregular terrain -realization of walking in outdoor environment using a self-contained robot: 'Tekken2'-," Journal of the Robotics Society of Japan, vol.25, no.1, pp.138-154, 2007.

[7] I. Fukuyori, Y. Nakamura, Y. Matsumoto and H. Ishiguro: "Control method for a robot based on adaptive attractor selection model," The 4-th International Conference on Autonomous Robots and Agents (ICARA 2009), pp.618-623, 2009.

[ 8 ] K. Hirai, M. Hirose, Y. Haikawa and T. Takenaka: "The development of honda humanoid robot," Proceedings of the 1998 IEEE International Conference on Robotics \& Automation, pp.1321-1326, 1998

[9] T. Kanda, M. Shiomi, Z. Miyashita, H. Ishiguro and N. Hagita: "An affective guide robot in a shopping mall," 4th ACM/IEEE International Conference on Human-Robot Interaction (HRI2009), pp.173-180, 2009.

[10] K. Kaneko and C. Furusawa: "Consistency principle in biological dynamical systems," Theory in biosciences, vol.127, pp.195-204, 2008.

[11] A. Kashiwagi, I. Urabe, K. Kaneko and T. Yomo: "Adaptive response of a gene network to environment changes by fitnessinduced attractor selection," PLoS ONE, vol.1, 2006.

[12] M. Kawato: "Internal models for motor control and trajectory planning," Current opinion in neurobiology, vol.9, pp.718-727,
1999.

[13] J.E. Levin and J.P. Miller: "Broadband neural encoding in the cricket cercal sensory system enhanced by stochastic resonance," nature, vol.380, pp.165-168, 1996.

[14] R.M. Macnab: "The gradient-sensing mechanism in bacterial chemotaxis," Proc. Nat. Acad. Sci. USA, vol.69, no.9, 1972.

[15] Y. Nakamura, T. Mori, M. Sato and S. Ishii: "Reinforcement learning for a biped robot based on a cpg-actor-critic method," Neural Networks, vol.20, no.6, pp.723-735, 2007.

[16] S.G. Nurzaman, Y. Matsumoto, Y. Nakamura, S. Koizumi and H. Ishiguro: "Biologically inspired adaptive mobile robot search with and without gradient sensing," 2009 IEEE/RSJ International Conference on Intelligent Robots and Systems (IROS 2009), pp.142-147, 2009.

[17] K. Sato, Y. Ito, T. Yomo and K. Kaneko: "On the relation between fluctuation and response in biological systems," PNAS, vol.100, no.24, pp.14086-14090, 2003.

[18] L.M. Schmitt: "Theory of genetic algorithm," Theoretical Computer Science, vol.259, pp.1-61, 2001.

[19] K. Shirai, Y. Matsumoto, Y. Nakamura, S. Koizumi and H. Ishiguro: "Noise-based underactuated mobile robot inspired by bacterial motion mechanism," 2009 IEEE/RSJ International Conference on Intelligent Robots and Systems (IROS 2009), pp.1043-1048, 2009.

[20] R.S. Sutton and A.G. Barto: Reinforcement Learning: An Introduction. MIT Press, 1998.

[21] G. Taga, Y. Yamaguchi and H. Shimizu: "Self-organized control of bipedal locomotion by neural oscillators in unpredictable environment," Biological Cybernetics, vol.65, pp.147159, 1991.

[22] H. Takagi, M.J. Sato, T. Yanagida and M. Ueda: "Functional analysis of spontaneous cell movement under different physiological conditions," PLoS ONE, vol.3, no.7, p.e2648, 2008.

[23] G.M. Viswanathan, S.V. Buldyrev, S. Havlin, M.G.E. da Luz, E.P. Raposo and E. Stanley: "Optimizing the success of random searches," nature, vol.401, pp.911-914, 1999.

[24] T. Yanagida: "Fluctuation as a tool of biological molecular machines," Bio Systems, vol.93, pp.3-7, 2008.

[25] T. Yanagida, M. Ueda, T. Murata, S. Esaki and Y. Ishii: "Brownian motion, fluctuation and life," Biosystems, vol.88, no.3, pp.228-242, 2006.

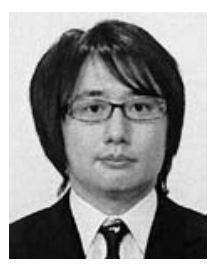

中村 泰 (Yutaka Nakamura)

2004 年奈良先端科学技術大学院大学情報科学研究 科修了. 博士 (工学). 同年奈良先端科学技術大学 院大学情報科学研究科研究員. 2006 年大阪大学大 学院工学研究科知能・機能創成工学専攻助手. 2007 年同大学助教. 知能ロボット, 機械学習の研究に興 味を持つ

（日本ロボット学会正会員）

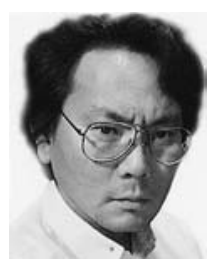

石黒 浩 (Hiroshi Ishiguro)

1991 年大阪大学大学院基礎工学研究科物理系専攻 修了. 工学博士. 同年山梨大学工学部情報工学科助 手. 1992 年大阪大学基礎工学部システム工学科助 手. 1994 年京都大学大学院工学研究科情報工学専 攻助教授, 1998 年同大学大学院情報学研究科社会 情報学専攻助教授.この間, 1998 年より 1 年間, カ リフォルニア大学サンディエゴ校客員研究員. 2000 年和歌山大学シス テム工学部情報通信システム学科助教授，2001 年同大学教授. 2002 年大阪大学大学院工学研究科知能 - 機能創成工学専攻教授, 2009 年上 り同大学大学院基礎工学研究科システム創成専攻教授. 1999 年 ATR 知能映像研究所客員研究員, 2002 年より ATR 知能ロボティクス研 究所客員室長. 知能ロボット, アンドロイドロボット, 知覚情報基盤 の研究に興味を持つ。

(日本ロボット学会正会員)

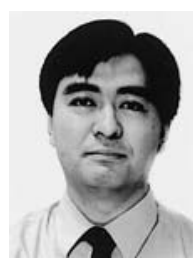

松本吉央（Yoshio Matsumoto）

1998 年東京大学大学院工学系研究科博士課程修了. 博士 (工学). 1998 年オーストラリア国立大学情 報理工学研究科研究員. 1999 年奈良先端科学技術 大学院大学情報科学研究科助手, 2002 年同助教授. 2007 年大阪大学大学院工学研究科特任教授. 2009 年より独立行政法人産業技術総合研究所知能システ ム研究部門サービスロボティクス研究グループ長．実環境で活動する サービスロボットの実現に興味を持つ。情報処理学会, 電子情報通信 学会会員.

(日本ロボット学会正会員) 